\title{
Comparative Study of Immunomodulatory Agents to Induce Human T Regulatory (Treg) Cells: Preferential Treg-Stimulatory Effect of Prednisolone and Rapamycin
}

\author{
Michał Janyst ${ }^{1,3} \cdot$ Beata Kaleta $^{2} \cdot$ Karolina Janyst $^{1,3} \cdot$ Radosław Zagożdżon $^{2} \cdot$ Ewa Kozlowska $^{4} \cdot$ Witold Lasek $^{1}$ (D)
}

Received: 30 May 2019 / Accepted: 18 May 2020 / Published online: 12 June 2020

(c) The Author(s) 2020

\begin{abstract}
$\mathrm{T}$ regulatory (Treg) cells play a critical role in the maintenance of self-tolerance, as well as in inhibition of inflammation and exaggerated immune response against exogenous antigens. They develop in the thymus (tTreg cells) but also may be generated at the peripheral tissues, including tumor microenvironment (pTreg cells), or induced in vitro in the presence of transforming growth factor (TGF)- $\beta$ (iTreg cells). Since tTreg cells constitute a minor fraction of peripheral blood lymphocytes in physiological conditions, an alternative way to obtain high number of functional Treg cells for therapeutic purposes is their generation in vitro from conventional T cells. In our studies, we compared effectiveness of several pharmacological agents with suggested immunomodulatory effects on Treg development (rapamycin, prednisolone, inosine pranobex, glatiramer acetate, sodium butyrate, and atorvastatin) to optimize Treg-inducing protocols. All but one (atorvastatin) immunomodulators augmented induction of polyclonal Treg cells in cultures. They were effective both in increasing the number of $\mathrm{CD} 4{ }^{+} \mathrm{CD} 25^{\text {high }}$ Foxp $3^{\text {high }}$ cells and Foxp3 expression. Rapamycin and prednisolone were found the most effective. Both drugs prolonged also phenotypic stability of Treg cells and induced fully active Treg cells in a functional assay. In the assay, prednisolone appeared superior versus rapamycin. The results, on the one hand, may be helpful in planning optimal protocols for generation of Treg cells for clinical application and, on the other hand, shed some light on mechanisms of the immunomodulatory activity of some tested agents observed in vivo.
\end{abstract}

Keywords Treg cells $\cdot$ Prednisolone $\cdot$ Rapamycin $\cdot$ Glatiramer acetate $\cdot$ Inosine pranobex $\cdot$ Atorvastatin

\section{Introduction}

$\mathrm{T}$ regulatory (Treg) cells are a fraction of $\mathrm{CD}^{+} \mathrm{T}$ lymphocytes responsible for suppression of immune response (Sakaguchi et al. 2008). Their number is low in neonates but in adults, probably due to immunomodulatory effects of environmental factors, percentage of Tregs is increased

Witold Lasek

witold.lasek@wum.edu.pl

1 Department of Immunology, Centre of Biostructure Research, Medical University of Warsaw, Warsaw, Poland

2 Department of Clinical Immunology, Medical University of Warsaw, Warsaw, Poland

3 Postgraduate School of Molecular Medicine, Medical University of Warsaw, Warsaw, Poland

4 Department of Immunology, Faculty of Biology, University of Warsaw, Warsaw, Poland
(Zahran et al. 2019). Although Treg cells constitute minority of $\mathrm{CD}^{+}{ }^{+} \mathrm{T}$ lymphocytes in blood, these cells play a crucial role in maintaining homeostasis of the immune system (Whibley et al. 2019). Their functions include: prevention of autoimmune diseases by maintaining self-tolerance, suppression of hypersensitivity reactions, induction of tolerance against dietary antigens, induction of maternal tolerance to the fetus, and induction of tolerance to the allograft (Bocian et al. 2017). Malfunction of Treg cells leads to development of many diseases such as allergies, autoimmune and inflammatory diseases, and many other (Lan et al. 2012; Lee et al. 2017; Martín-Orozco et al. 2017).

According to recent recommendations, Treg cells-in respect of their origin and development — can be divided into three different subpopulations (Abbas et al. 2013). Thymically derived $\mathrm{T}$ regulatory cells (tTregs, formerly natural Tregs-nTregs) constitute a fraction of Treg cells developed in the thymus and are engaged in recognition of autoantigens and TCR/MHC interactions of high affinity. 
Peripherally derived $\mathrm{T}$ regulatory cells (pTregs, formerly induced Tregs-iTregs) develop in vivo during suboptimal stimulation of $\mathrm{T}$ cell receptor (TCR), but require also additional factors, such as transforming growth factot (TGF) $\beta$ (Horwitz et al. 2008; Kretschmer et al. 2005). Expansion of pTregs is related to many physiological or pathological processes. They can arise, for example, following presentation of alloantigens by dendritic cells, after stimulation by metabolites produced by commensal bacteria-to prevent exaggerated immune response against microbiota, and as a result of chronic inflammatory pathologies such as inflammatory bowel diseases (Arpaia et al. 2013). The third fraction of $\mathrm{T}$ regulatory cells includes iTregs-in vitro-induced $\mathrm{T}$ regulatory cells. They are generated from conventional $\mathrm{T}$ cells in vitro in cultures supplemented with TGF- $\beta$ (Schmitt and Williams 2013; Zheng et al. 2002). All the Treg cells have characteristic phenotype: $\mathrm{CD} 4^{+}, \mathrm{CD} 25^{\text {high }}$, Foxp $3^{+}$ and low expression of CD127 (Liu et al. 2006). They also express CTLA-4, GITR, CCR4 and CD62L markers (Horwitz et al. 2008). There is a general view that tTreg cells are preferentially engaged in blocking autoimmune reactions, while pTreg cells are necessary mainly for prevention of excessive response against exogenous antigens.

Due to a potent suppressive potential, Treg cells can be used in the treatment of diseases in which immune reactions are excessive. Effectiveness of the treatment was documented for the first time in patients with ongoing graftversus-host disease (GVHD) after hematopoietic stem cell transplantation (Trzonkowski et al. 2009a). The treatment resulted in improvement patients' condition and allowed lowering glucocorticoid doses. What is more, no significant side effects were observed. At present, most clinical trials based on infusion of ex vivo expanded tTreg cells have been performed in the prophylaxis or treatment of GVHD but the Treg cell transfer may be also beneficial in the treatment of some autoimmune diseases: type I diabetes, myasthenia gravis and lupus erythematosus (Gliwiński et al. 2017). However, to obtain clinically meaningful effects, high number of tTreg cells for infusion is necessary. Since tTreg cells constitute a minor fraction of peripheral blood $\mathrm{CD} 4^{+} \mathrm{T}$ cells and they are characterized by low proliferative index, there are some problems with obtaining the final product of high purity (Gliwiński et al. 2017). Moreover, only some of sorted cells are efficient suppressors (Trzonkowski et al. 2009b). Furthermore, some studies have demonstrated tTreg instability and dysfunction in the inflammatory condition following infusion (Lan et al. 2012; Lu et al. 2014).

To overcome the mentioned above obstacles, attempts are being made to generate in vitro iTreg cells in sufficient number from conventional $\mathrm{CD} 4^{+} \mathrm{T}$ cells, using for example rapamycin or all-trans retinoic acid (Candia et al. 2017). This cells could mimic peripheral Treg cells and may be especially beneficial in hyperactive immune pathologies including chronic inflammatory diseases associated with tissue destructions.

In the present study we verified the ability of various pharmacological agents with suggested modulatory effect on Treg cell development/activity: rapamycin (Fanigliulo et al. 2015; Li et al. 2014), prednisolone (Karagiannidis et al. 2004; Mathian et al. 2015), atorvastatin (Forero-Peña and Gutierrez 2013), inosine pranobex, sodium butyrate (Fontenelle and Gilbert 2012), and glatiramer acetate (Haas et al. 2009; Hong et al. 2005) to facilitate/augment generation of iTreg cells in standard in vitro cultures, with the aim to further investigations for clinical application.

\section{Materials and Methods}

\section{Human T Cell Isolation}

Peripheral blood mononuclear cells (PBMCs) were prepared from buffy coats obtained from the Regional Centre of Blood Donation and Blood Therapy (Warsaw, Poland). The cells were isolated by Ficoll-Hypaque (Histopaque-1077, SigmaAldrich, St. Louis, MO, USA) density gradient centrifugation. After washing in phosphate-buffered saline (PBS), PBMCs were counted and suspended in culture medium [RMPI medium supplemented with antibiotics (penicillin, $100 \mathrm{U} / \mathrm{ml}$ and streptomycin, $0.1 \mathrm{~g} / \mathrm{L}$ ) + antimycotic (Amphotericin B, $0.25 \mathrm{mg} / \mathrm{L}$ ) (Sigma-Aldrich) and 10\% heat-inactivated fetal bovine serum (Gibco-Invitrogen, Grand Island, NY, USA)], aliquoted in cryotubes, frozen and transferred to liquid nitrogen. $\mathrm{CD} 4^{+} \mathrm{T}$ cells were isolated from PBMCs before experiments by a negative selection method, using magnetic-activated cell sorting (MACS) system $\left(\mathrm{CD} 4^{+} \mathrm{T}\right.$ cell isolation kit; MiltenyiBiotec, BergischGladbach, Germany). The purity of isolated $\mathrm{CD} 4^{+}$cells was assessed using flow cytometry and confirmed to be $>96 \%$.

\section{iTreg Differentiation}

Following MACS separation, $\mathrm{CD} 4^{+} \mathrm{T}$ cells were cultured in 24 flat-bottom well plates at a concentration of $2 \times 10^{5}$ cells/well in culture medium. For Tregs induction, cells were stimulated with CD3/CD28 beads $\left(0.25 \times 10^{5} / \mathrm{ml}\right)$ (Dynabeads Human T-activator, Thermo Fisher Scientific, Waltham, MA, USA), in the presence of TGF- $\beta 1(2 \mathrm{ng} / \mathrm{ml})$ (PeproTech, London, UK). To prevent proliferation of tTreg cells with high expression of CD25, interleukin (IL)-2 was not added to cultures. The following agents were tested for their action on Treg cell development: sodium butyrate (Sigma Aldrich) (final concentrations: 4, 20, 100, $500 \mu \mathrm{M}$ ), glatiramer acetate (final concentrations: $1,5,25,125 \mu \mathrm{g} / \mathrm{ml}$ ), inosine pranobex (Gedeon Richter Polska, Poland) (final concentrations: 50, 100, $200 \mathrm{mg} / \mathrm{ml}$ ), rapamycin (Sigma 
Aldrich) (final concentrations: 4, 20, 100, 500, 2500 ng/ml), prednisolone (Sigma Aldrich) (final concentrations: 2.5, 25, $250,2500,25,000 \mathrm{ng} / \mathrm{ml}$ ), atorvastatin (final concentrations: $1.6,8,40,200,1000 \mathrm{ng} / \mathrm{ml}$ ) or acetic acid (final concentrations: 4, 20, 100, $500 \mu \mathrm{M})$. The cells were incubated for 5 days, followed by FACS analysis.

\section{Flow Cytometry and Antibodies}

The phenotype of $\mathrm{CD}^{+}{ }^{+} \mathrm{T}$ cells was determined based on CD25 and Foxp3 markers. Surface antigens CD4 and CD25 were stained with anti-CD4-PerCP (clone SK 3, BD Biosciences, USA) and anti-CD25-FITC (clone M-251; BD Biosciences) monoclonal antibodies in the dark for $20 \mathrm{~min}$ at $4{ }^{\circ} \mathrm{C}$. Following staining, the cells were washed twice with PBS and stained intracellularly with Foxp3-PE Staining Kit (clone PCH101; eBioscience, USA) according to manufacturer's protocol. Acquisition was performed on BD Accuri C6 (BD Biosciences). FACS data were analyzed using FlowJo.

\section{Functional Testing of Treg Inhibitory Activity in MLR}

To evaluate the in vitro immunosuppressive activity of induced Treg cells (iTreg), mixed lymphocyte reaction (MLR) was performed. Following 5 days of iTreg differentiation, the cells were isolated from cultures using MACS system ( $\mathrm{T}$ regulatory cell isolation kit; MiltenyiBiotec, BergischGladbach, Germany). The purity of isolated Treg cells was assessed using flow cytometry and confirmed to be $>96 \%$. Isolated iTregs rested for 2 days in culture medium with addition of IL-2 (50 IU/ml) (Proleukin; Novartis, Switzerland). In the next step, freshly isolated allogenic PBMCs were inactivated by gamma irradiation for $90 \mathrm{~min}$ and served as stimulators (PBMC-stim). In the assay, $1 \times 10^{5}$ stimulatory cells were incubated with $1 \times 10^{5}$ responder $\mathrm{CD} 4^{+} \mathrm{T}$ cells (Tresp) and co-cultured with $0.5 \times 10^{5}, 0.25 \times 10^{5}$, or $0.125 \times 10^{5}$ autologous regulatory $\mathrm{T}$ cells. Cells were cultured in 96 -well flat-bottom plates at $37^{\circ} \mathrm{C}$ in a humidified atmosphere with $5 \% \mathrm{CO}_{2}$. After 5 days, cultures were pulsed with $1 \mu \mathrm{Ci} /$ well of ${ }^{3} \mathrm{H}$-thymidine $(113 \mathrm{Ci} / \mathrm{nmol}$, NEN, Life Science Products, Zaventem, Belgium) for the last $18 \mathrm{~h}$ of the incubation and harvested with an automated cell harvester (Skatron). The amount of ${ }^{3} \mathrm{H}$-thymidine incorporated into the proliferating cells was measured using a Wallac Microbeta scintillation counter (Wallac), giving the level of radioactivity as "corrected counts per minute" (cpm). Experiments were performed in triplicates.

\section{Cytokines}

Cytokine concentrations in supernatants were measured using a LEGENDplex ${ }^{\mathrm{TM}}$ bead-based cytokine kit (BioLegend,
USA), according to the manufacturer's protocol. On day 0 , cells were plated in 24 flat-bottom well plates at a concentration of $8 \times 10^{5}$ cells $/ 0.8 \mathrm{ml} /$ well supplemented with CD3/CD28 beads, TGF- $\beta 1$ (see “iTreg Differentiation" section), and prednisolone or rapamycine. On day 5 , supernatants were discarded and replaced with fresh culture medium. After 2-day resting period culture supernatants were harvested, centrifuged, and kept frozen until the cytokine analysis procedure.

\section{Analysis of Stability of Induced Treg Cells}

After 5 days of Treg induction in the presence of either prednisolone or rapamycin (see "iTreg Differentiation" section), culture medium was discarded and replaced with medium containing $50 \mathrm{U} / \mathrm{ml}$ IL-2 (Proleukin, Novartis). The cells were then incubated for the next 4 days followed by FACS analysis of Treg markers.

\section{Statistical Analysis}

Differences between samples with or without addition of the same immunomodulator were examined using paired Student's $t$ test. Differences between samples with or without addition of different immunomodulator in mixed lymphocytes reaction assay was examined using unpaired Student's $t$ test. $P$ smaller than 0.05 was considered as significant.

\section{Results}

\section{Induction of $\mathrm{CD}^{+}{ }^{+} \mathrm{CD} 25^{\text {high }}$ Foxp $3^{\text {high }}$ Treg Cells}

In preliminary experiments, optimal conditions for Treg cell differentiation were established: $\mathrm{CD}^{+}{ }^{+} \mathrm{T}$ cells were stimulated by CD3/CD28 beads in the presence of TGF- $\beta$. The number of Treg cells (recognized as $\mathrm{CD} 4^{+} \mathrm{CD} 25^{\text {high }} \mathrm{Foxp} 3^{\text {high }}$ cells), as well as expression of Foxp3, was the highest in the fifth day of incubation. The dose of CD3/CD28 beads was adjusted so that differentiating $\mathrm{CD}^{+}{ }^{+} \mathrm{T}$ lymphocytes were not overstimulated (CD3/CD28 beads to T cell ratio 1:8). Similarly, the dose of TGF- $\beta(2 \mathrm{ng} / \mathrm{ml})$ was suboptimal. We assumed that high doses of TGF- $\beta$ could lead to maximum level of differentiation of $\mathrm{CD} 4^{+} \mathrm{T}$ cells to Tregs, which could prevent further augmentation by examined immunomodulators. Identification of iTreg cells is presented in Fig. 1.

\section{Stimulation of $\mathrm{CD}^{+} \mathrm{T}$ cells in Presence of Rapamycin, Prednisolone, Glatiramer Acetate, Sodium Butyrate or Inosine Pranobex Leads to Increased Proportion of Treg Cells in Cultures}

First, we investigated the ability of a panel of immunomodulatory agents to increase differentiation of $\mathrm{CD}^{+}$ $\mathrm{T}$ cells incubated with $\mathrm{CD} 3 / \mathrm{CD} 28$ beads and TGF- $\beta$ to 

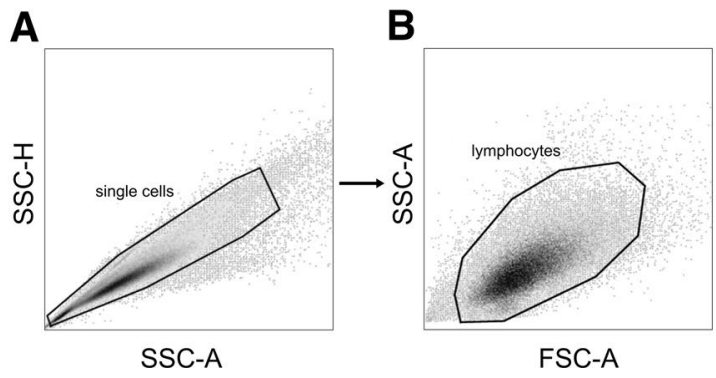

Fig. 1 Identification of induced Treg cells. a Treg cells were generated from $\mathrm{CD}^{+}{ }^{+} \mathrm{T}$ cells incubated with $\mathrm{CD} 3 / \mathrm{CD} 28$ beads and TGF- $\beta$ for 5 days. The cells were analyzed by FACS. b Primary gate was set on lymphocytes depending on their forward and side scatter prop-

$\mathrm{CD} 4{ }^{+} \mathrm{CD} 25^{\text {high }}$ Foxp $3^{\text {high }}$ cells. Co-culture of $\mathrm{CD} 4{ }^{+} \mathrm{T}$ lymphocytes with immunomodulators resulted in an increase of Tregs in comparison to TGF- $\beta$ alone, in a dose-dependent manner. The strongest effect was observed in cultures with prednisolone concentration of $250 \mathrm{ng} / \mathrm{ml}$ and more (Fig. 2a, representative FACS graphs are presented in Fig. 3), rapamycin ( $4 \mathrm{ng} / \mathrm{ml}$ and more, Fig. 2 b), sodium butyrate ( 20 and $100 \mu$ M, Fig. 2c), glatiramer acetate (125 ng/ml, Fig. 2d), and inosine pranobex $(200 \mathrm{mg} / \mathrm{ml}$, Fig. 2e). In comparison with rapamycin, prednisolone was found to inhibit proliferation of $\mathrm{CD}^{+}{ }^{+} \mathrm{T}$ cells (stimulated with $\mathrm{CD} 3 / \mathrm{CD} 28$ beads in the presence of TGF- $\beta$ ) to a much lesser extent. Significantly lower number of cells was observed in cultures with the highest concentration of prednisolone $(25 \mu \mathrm{g} / \mathrm{ml})$, while rapamycin decreased number of cells already at a dose of $100 \mathrm{ng} / \mathrm{ml}$ (and higher) (Table 1). Incubation of lymphocytes with atorvastatin or acetic acid (used as a control for butyrate) did not lead to significant increase in proportion of Treg cells (Fig. 2f, g).

Induction of Treg cells in the presence of the tested agents was also associated with augmented expression of Foxp3 (apart from atorvastatin and acetic acid). The expression of Foxp3 was the highest in $\mathrm{CD}^{+} \mathrm{T}$ cells incubated with prednisolone and rapamycin. High concentrations of prednisolone $(25 \mu \mathrm{g} / \mathrm{ml})$ and rapamycin $(500 \mathrm{ng} / \mathrm{ml})$ resulted in a 2.11-fold and 2.38-fold, respectively, increase in Foxp3 median florescence intensity (MFI) compared with control samples $\left(\mathrm{CD}^{+}{ }^{+} \mathrm{T}\right.$ lymphocytes stimulated with $\mathrm{CD} 3 / \mathrm{CD} 28$ beads in the presence of TGF- $\beta$ ) (Table 2).

\section{Treg Cells Generated in the Presence of Prednisolone and Rapamycin are Suppressive in a Functional Assay}

Activation of $\mathrm{CD} 4{ }^{+} \mathrm{T}$ cells in the presence of TGF- $\beta$ significantly increased number of Treg cells and most of the tested drugs/compounds enhanced this effect. Prednisolone and rapamycin seemed the most effective in this activity (Figs. 2,

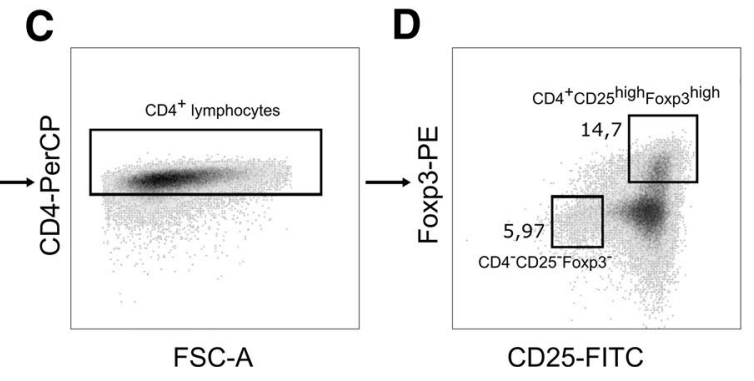

erties. c Secondary gate was set on $\mathrm{CD}^{+} \mathrm{T}$ lymphocytes. d Treg cells were identified using anti-CD25 and anti-Foxp3 antibodies as $\mathrm{CD} 4{ }^{+} \mathrm{CD} 25^{\text {high }}$ Foxp $3^{\text {high }}$ cells. Numbers show percentage of gated cells

3). However, it was interesting if the induced Treg cells were functional. To test this hypothesis, activity of Treg cells generated in the presence of prednisolone or rapamycin were investigated in allogeneic MLR. As shown in Fig. 4, Treg cells from cultures incubated with prednisolone or rapamycin effectively suppressed proliferation of allo-stimulated $\mathrm{T}$ cells in MLR. Interestingly, while Treg cells generated in cultures with rapamycin showed similar suppressive activity when compared to control cultures, prednisolone-activated Treg cells were found superior and exerted significantly stronger suppressive effect (Fig. 4a). This effect could be related, in part, to higher number of Treg cells in cultures with prednisolone since higher rate of proliferation was observed in Treg cultures stimulated by allogeneic cells in the presence of prednisolone than with rapamycin (Fig. 4b). Certainly, an analysis of immunosuppressive cytokines and iTreg stability (e.g., assessment of Treg-specific demethylation region-TSDR), in prednisolone cultures could support superiority of prednisolone over rapamycin. Prednisolonegenerated Treg cells exerted measurable inhibitory effect in MLR at 1:0.5 but also at 1:0.25 Tresp-to-Treg cell ratio (Fig. 4c).

\section{Prednisolone and Rapamycin Prolong Phenotypic Stability of iTreg Cells}

To effectively control inflammation and excessive immune response, Treg stability should be maintained over time even in the absence of Treg-promoting stimuli. To answer the question if the Treg-promoting effect of prednisolone and rapamycin is transient or permanent, we cultured the cells after 5 days of Treg induction for additional 4 days in the presence of IL-2 only. As presented in Table 3, in contrast to a significant loss of regulatory phenotype of cells activated only in the presence of TGF$\beta$, percentage of $\mathrm{CD} 4^{+} \mathrm{T}$ cells expressing Treg markers (CD25 ${ }^{\text {high }}$ Foxp $\left.3{ }^{\text {high }}\right)$ was much higher in resting cultures primarily activated with addition of either prednisolone or 
A

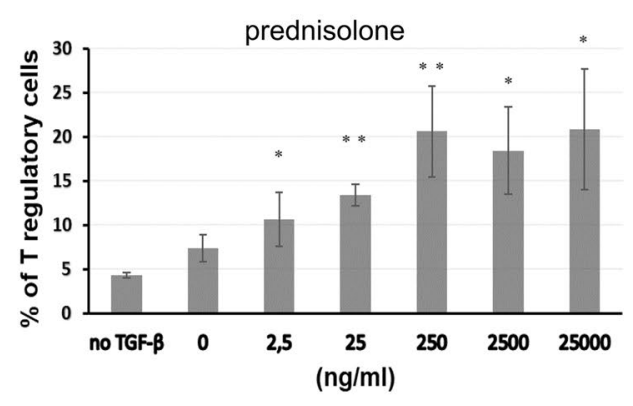

C

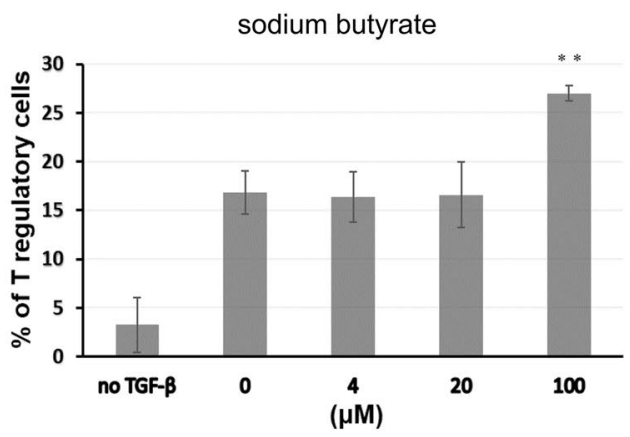

E

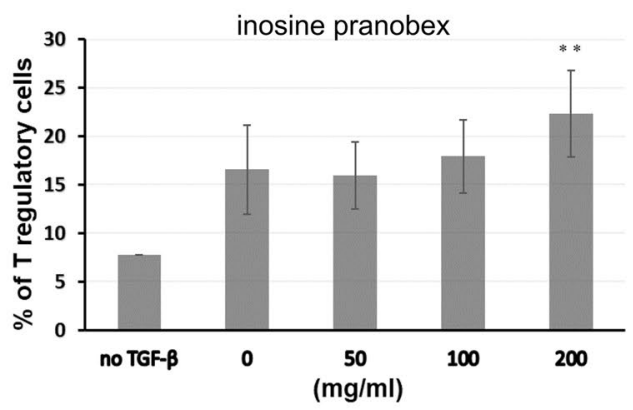

G

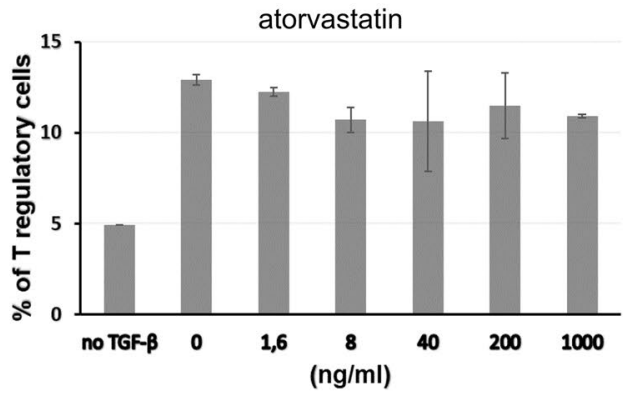

Fig. 2 Frequency of Treg cells in cultures with different immunomodulators. Cells were analyzed following 5 days of culture with CD3/CD28 beads, TGF- $\beta$ and immunomodulators (for details, see "Materials and Methods"). CD4 ${ }^{+} \mathrm{T}$ lymphocytes were co-cultured

rapamycin. Treg-promoting effect of prednisolone is especially notable, since a proportion of Treg cells was preserved in a 4-day resting cultures of cells primarily generated in the presence of prednisolone even when no IL-2 was added to cultures (5.5\% vs. $1.21 \%$, when compared to
B

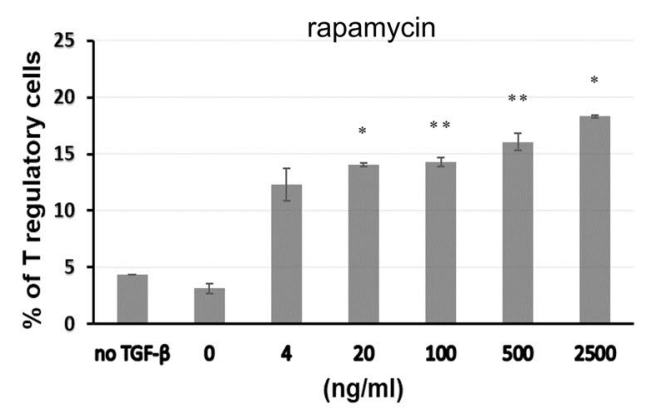

D

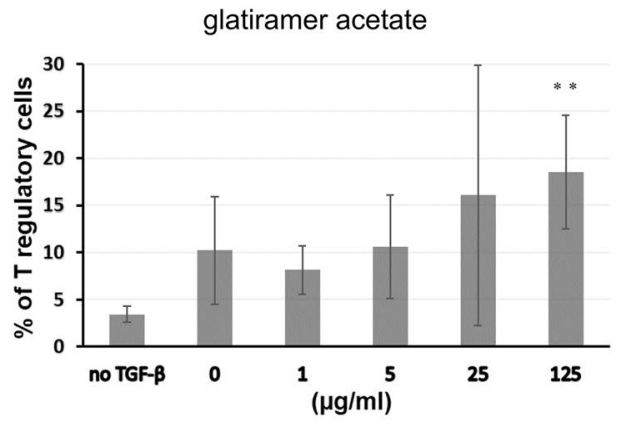

$\mathbf{F}$

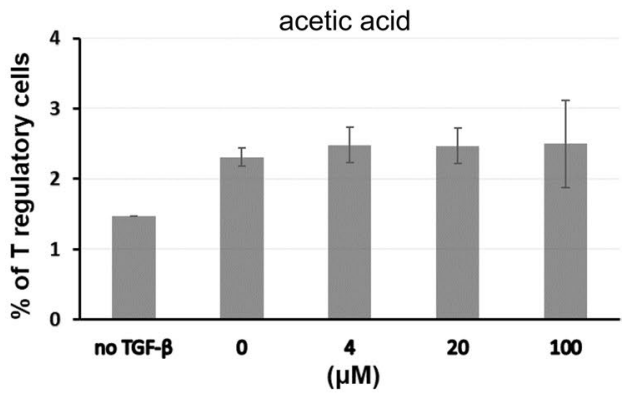

with prednisolone (a), rapamycin (b), sodium butyrate (c) glatiramer acetate (d), inosine pranobex (e), acetic acid (used as a negative control for butyrate) (f), and atorvastatin (g). ${ }^{*} p<0.05, * * p<0.01$ vs. culture with no immunomodulator

primary activation with TGF- $\beta$ only). However, during a 4-day resting period, expression of Foxp3 decreased significantly, both in Treg cells that were primarily induced with TGF- $\beta$ only and in cells co-incubated with either prednisolone or rapamycin (data not shown). 


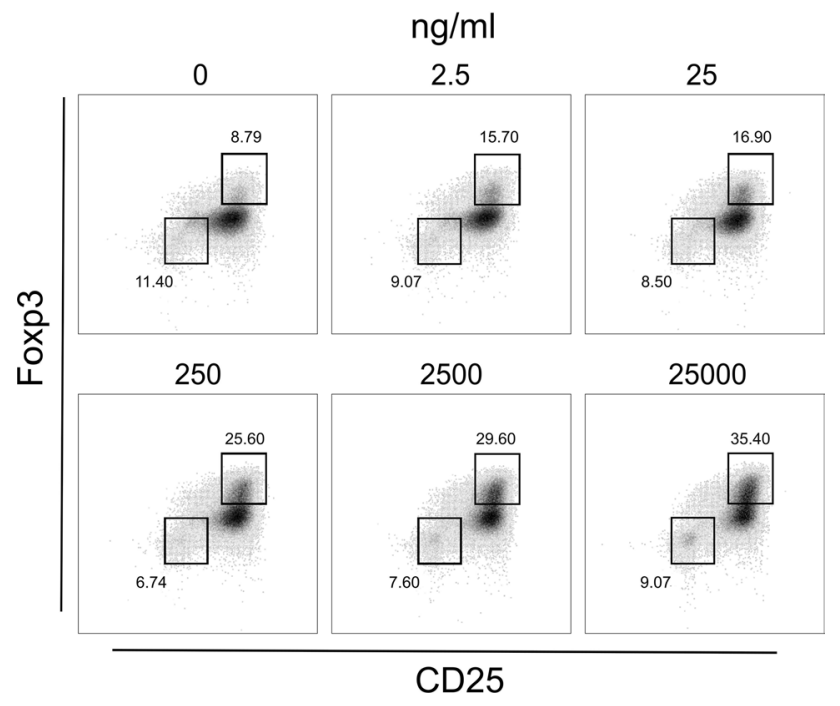

Fig. 3 Frequency of Treg cells in cultures with increasing concentrations of prednisolone. $\mathrm{CD}^{+} \mathrm{T}$ cells were incubated with $\mathrm{CD} 3$ / CD28 beads, TGF- $\beta$ and increasing doses of prednisolone. Cells were analysed after 5 days of incubation (for details, see "Materials and Methods"). Gates were set on $\mathrm{CD} 4^{+} \mathrm{CD} 25^{-} \mathrm{Foxp}^{-}$and $\mathrm{CD} 4^{+} \mathrm{CD} 25^{\text {high }}$ Foxp $3^{\text {high }}$ cells. Results are representative for three independent experiments

Table 1 Recovery of lymphocytes in stimulated cultures incubated with prednisolone or rapamycin

\begin{tabular}{llll}
\hline $\begin{array}{l}\text { CD3/CD28 } \\
\text { beads }\end{array}$ & TGF- $\beta$ & Immunomodulator & $\begin{array}{l}\text { Number of } \\
\text { cells } \times 10^{5} \\
(\text { mean } \pm \text { SD) }\end{array}$ \\
\hline+ & + & Prednisolone & \\
& & $25 \mu \mathrm{g} / \mathrm{ml}$ & $1.52 \pm 0.13^{*}$ \\
& & $2.5 \mu \mathrm{g} / \mathrm{ml}$ & $1.79 \pm 0.44$ \\
& & $0.25 \mu \mathrm{g} / \mathrm{ml}$ & $1.78 \pm 0.43$ \\
+ & + & Rapamycin & \\
& & $2500 \mathrm{ng} / \mathrm{ml}$ & $1.28 \pm 0.17^{* *}$ \\
& & $500 \mathrm{ng} / \mathrm{ml}$ & $1.31 \pm 0.30^{* *}$ \\
& & $100 \mathrm{ng} / \mathrm{ml}$ & $1.48 \pm 0.32^{* *}$ \\
+ & + & - & $2.42 \pm 0.38$ \\
+ & - & - & $2.99 \pm 0.54$ \\
\hline
\end{tabular}

$\mathrm{CD}^{+} \mathrm{T}$ cells $\left(2 \times 10^{5}\right)$ were stimulated for five days with CD3/CD28 beads (supplemented with TGF- $\beta$ ) in the presence of prednisolone or rapamycin

${ }^{*} p<0.05, * * p<0.01$, vs. cell culture stimulated with $\mathrm{CD} 3 / \mathrm{CD} 28$ beads supplemented with TGF- $\beta$

\section{Effects of Prednisolone and Rapamycin on Cytokine Production in Cultures of iTreg Cells}

Function of Treg cells is mediated either by the direct cellto-cell contact or via cytokines, preferentially IL-10 and TGF- $\beta$. The cells, however, may produce and release other cytokines. In fact, Treg cells are plastic and may be converted into Th17 subpopulation in the presence of proinflammatory cytokines. To investigate if generation of iTreg cells in the presence of prednisolone or rapamycin may shape/ change their cytokine-production profile, we measured levels of IL-10 (representative immunosuppressive cytokine), IL-6 and tumor necrosis factor (TNF)- $\alpha$ (characteristic proinflammatory cytokines) in respective cultures. As shown in Table 4, neither prednisolone nor rapamycin significantly affected the ability of induced Treg cells to produce IL-10 and TNF- $\alpha$. What is interesting, despite the large interindividual variation in cytokine production, iTreg generated in the presence of prednisolone seemed to produce smaller amounts of IL- 6 in comparison with activated cultures incubated with no TGF- $\beta$ or TGF- $\beta$ alone. This observation can have clinical translation, since IL-6 is recognized as the key cytokine promoting conversion of Tregs into Th17 cells (Schmitt and Williams 2013) and, as shown in recent studies by Fu et al. (2017), prednisone inhibits the ability of proinflammatory cytokines to stimulate differentiation of decidual immune cells into Th17 cells.

\section{Discussion}

In the present study we compared the ability of different pharmacological compounds (drugs), with suggested and real immunomodulatory activity, to promote generation of Treg cells from conventional $\mathrm{CD}^{+}{ }^{+} \mathrm{T}$ cells. In the literature, there is a lack of complex comprehensive analysis of the immunoregulatory potential of the compounds. We showed that rapamycin, prednisolone, sodium butyrate, glatiramer acetate and inosine pranobex, more or less efficiently and usually in a dose-dependent manner, increased the number of iTreg cells in cultures of activated CD4 ${ }^{+} \mathrm{T}$ cells in the presence of TGF- $\beta$. The highest percentage of $\mathrm{CD} 4{ }^{+} \mathrm{CD} 25^{\text {high }} \mathrm{Foxp} 3{ }^{\text {high }}$ lymphocytes appeared in cultures with prednisolone and rapamycin. However, it remains the open question if this high percentage resulted more from a direct promotion of Treg cells than from inhibition of nonTreg cell proliferation. In our study, atorvastatin and acetic acid neither exerted significant effects on induction of $\mathrm{T}$ regulatory cells nor affected expression of Foxp3.

Results of our studies shed light on mechanisms of the immunomodulatory effect of some tested compounds, explained discrepancies observed in studies of different authors and even demonstrated unpredictable effects. To induce Treg cells, in our experimental protocol TGF- $\beta$ was used in suboptimal concentration $(2 \mathrm{ng} / \mathrm{ml})$ and combined with immunomodulators that we could expect to enhance the TGF- $\beta$ effect. Results of the study could answer the cardinal clinical question: whether immunomodulators/drugs 
Table 2 Median Foxp3 expression (MFI) in Treg cells induced in cultures with different immunomodulatory agents

\begin{tabular}{lccl}
\hline Immunomodulator & $\begin{array}{l}\text { Foxp3 MFI in cultures } \\
\text { with immunomodulator } \\
(\text { median } \pm \text { SD })\end{array}$ & $\begin{array}{l}\text { Foxp3 MFI in con- } \\
\text { trols (median } \pm \text { SD) }\end{array}$ & Foxp3 MFI index ${ }^{\text {a }}$ \\
\hline Prednisolone & & & \\
$25 \mu \mathrm{g} / \mathrm{ml}$ & $7643 \pm 411$ & & $2.11^{* *}$ \\
$2.5 \mu \mathrm{g} / \mathrm{ml}$ & $6131 \pm 724$ & $3622 \pm 140$ & $1.69^{* *}$ \\
$0.25 \mu \mathrm{g} / \mathrm{ml}$ & $5847 \pm 557$ & & $1.61^{* * *}$ \\
Rapamycin & & & \\
$500 \mathrm{ng} / \mathrm{ml}$ & $8374 \pm 780$ & $3525 \pm 57$ & $2.38^{*}$ \\
$100 \mathrm{ng} / \mathrm{ml}$ & $7689 \pm 188$ & $7741 \pm 3372$ & $1.55^{*}$ \\
Sodium butyrate $(100 \mu \mathrm{M})$ & $11,962 \pm 6540$ & $6901 \pm 3512$ & 1.95 \\
Glatiramer acetate $(125 \mu \mathrm{g} / \mathrm{ml})$ & $13,437 \pm 8574$ & $5925 \pm 609$ & $1.30^{*}$ \\
Inosine pranobex $(200 \mathrm{mg} / \mathrm{ml})$ & $7699 \pm 1540$ & $3718 \pm 146$ & 0.98 \\
Acetic acid $(100 \mu \mathrm{M})$ & $3647 \pm 313$ & $5326 \pm 184$ & 0.95 \\
Atorvastatin $(1 \mu \mathrm{g} / \mathrm{ml})$ & $5080 \pm 62$ & & \\
\hline
\end{tabular}

Foxp3 expression was assessed in cultures of $\mathrm{CD}^{+} \mathrm{T}$ cells following 5-day stimulation (CD3/CD28 beads + TGF- $\beta$ ) in the presence of immunomodulatory agents

$* p<0.05, * * p<0.01, * * * p<0.001$

${ }^{\mathrm{a}}$ Foxp3 index represents Foxp3 immunomodulator to Foxp3 control ratio can augment physiological effect of TGF- $\beta$ in organs (compartments) in which this cytokine is produced in not high amounts.

Statins (including atorvastatin) are pharmacological inhibitors of the activity of 3-hydroxy-3-methyl-glutarylCoA reductase. Apart from inhibition of cholesterol synthesis, the drugs exert mild anti-inflammatory effect. This effect, in part, is dependent on Treg cells (Forero-Peña and Gutierrez 2013). Atorvastatin (but not mevastatin nor pravastatin) was shown to increase number of Treg cells in vitro (Mausner-Fainberg et al. 2008). On the contrary, Guasti et al. (2016) showed that atorvastatin (even in very high concentrations-5 $-5 \mathrm{M}$ ) did not affect PHA-induced Treg cells $\left(\right.$ Foxp $\left.3^{+}\right)$. Our studies are in agreement with the other study. The discrepancy between our studies and those by Mausner-Fainberg et al. (2008) can be explained in that they used much higher concentrations of atorvastatin, in non-stimulated cultures and, in fact, they tested the effect of the drug on natural tTreg cells.

Metabolites produced by gut microbiota (including shortchain fatty acids, such as butyric acid) in mice promote generation of pTreg cells and, jointly with direct anergizing effects on effector T cells, contribute to immunological homeostasis in the gut (Arpaia et al. 2013; Fontenelle and Gilbert 2012; Whibley et al. 2019). We confirmed the effect of butyrate on development of Treg cells in human CD4 ${ }^{+} \mathrm{T}$ cells and, in contrast to the study of Schmidt et al. (2016), we showed that the presence of IL-2 in culture is not obligatory in this phenomenon.

Glatiramer acetate (GA) is a pharmacological immunomodulatory agent approved for treatment of relapsing-remitting multiple sclerosis (Mitsikostas and Goodin
2017). Mechanisms of action of this drug have not been fully elucidated. Recent studies have demonstrated restoration of Treg cell function $\left(\mathrm{CD} 4^{+} \mathrm{CD} 127^{\text {low }} \mathrm{CD} 25^{\text {high }}\right)$ in patients following long-term treatment with GA (Spadaro et al. 2017). This effect seems to result from expansion of thymic Treg cells (Haas et al. 2009). Our studies, showing both increased number of cells with Treg characteristic and increased expression of Foxp3 marker in T cells incubated in the presence of GA (Fig. 2d, Table 2), demonstrate that inducible Treg cells may contribute to the overall therapeutic effect of this immunomodulator in patients with multiple sclerosis.

The original finding of our studies is showing the promoting effect of inosine pranobex (IP) (isoprinosine, inosine dimepranol acedoben) on Treg cell development. The agent is recognized as a mild immunostimulator, both in vitro and in vivo, with a direct antiviral activity (Campoli-Richards et al. 1986; Majewska et al. 2015). In our recent studies, in cultures of human lymphocytes, IP stimulated production of cytokines characteristic for Th1 response: interferon- $\gamma$ and TNF- $\alpha$ while inhibiting typical immunosuppressive cytokine IL-10 (Lasek et al. 2015). We cannot offer simple explanation of this paradoxical effects of IP on immune mechanisms. Maybe, the cytokine milieu during T cell activation is the clue. Systemic in vivo stimulation of effector T lymphocytes and general immunostimulatory effect of IP does not exclude its local effect on promotion of pTreg (in the presence of high concentrations of TGF- $\beta$ in the local environment).

Treg-enhancing effects of rapamycin and prednisolone deserve separate comments. Rapamycin is mammalian target of rapamycin inhibitor displaying strong immunosuppressive 
A

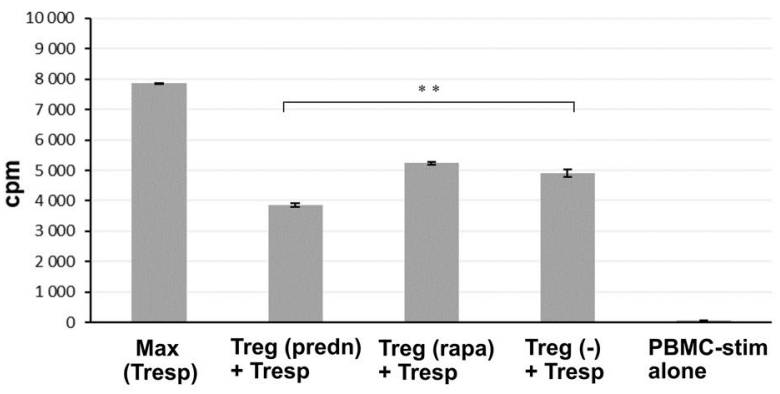

B

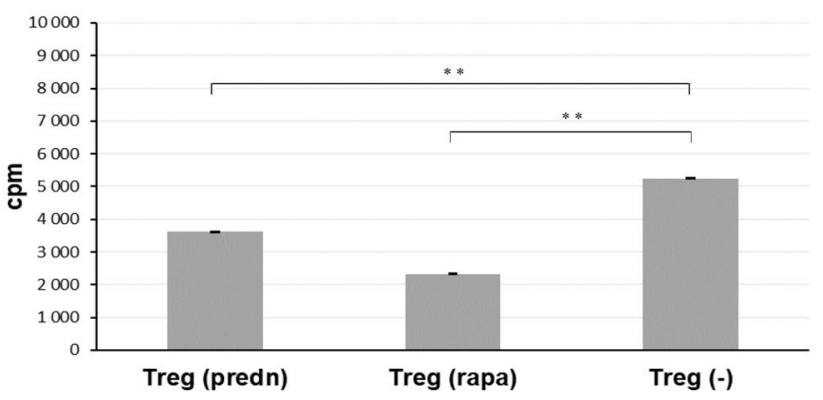

\section{C}

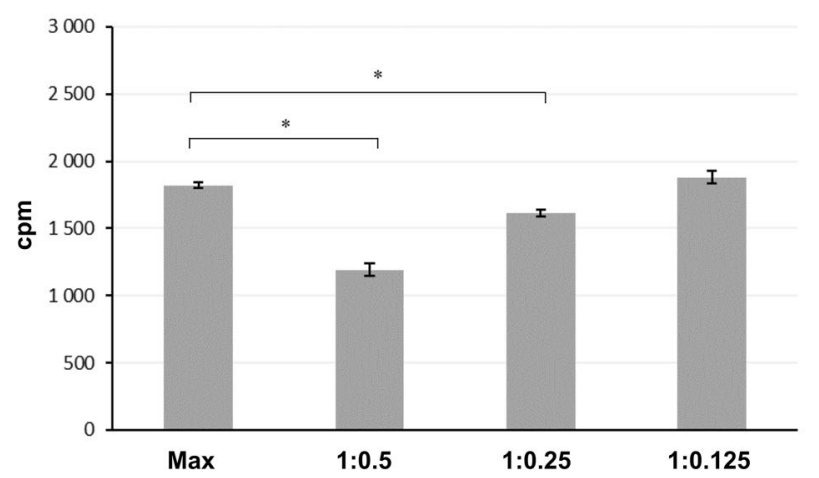

Fig. 4 a Suppression of allogeneic mixed lymphocyte reaction (MLR) by Treg cells generated in the presence of prednisolone or rapamycin. Tregs induced in 5-day cultures from $\mathrm{CD}^{+} \mathrm{T}$ cells incubated with $\mathrm{CD} 3 / \mathrm{CD} 28$ beads and TGF- $\beta$ in the presence of prednisolone $(250 \mathrm{ng} / \mathrm{ml})$ or rapamycin $(100 \mathrm{ng} / \mathrm{ml})$, as described in Materials and Methods, were incubated with allogeneic peripheral blood mononuclear cells (PBMC) (gamma-irradiated, PBMC-stim) and autologous responding $\mathrm{CD}^{+} \mathrm{T}$ cells (Tresp) for 5 days (to give PBMC-stim: Tresp: Treg ratio 1:1:0.5. $18 \mathrm{~h}$ before the end of incubation, $1 \mu \mathrm{Ci}{ }^{3} \mathrm{H}$-thymidine was added to each well. At the end of the culture, cells were harvested and maximal count per minute (cpm) was measured. For clarity, proliferation of Treg cells was subtracted. Results are representative for two independent experiments. Max (Tresp) $-\mathrm{cpm}$ in cultures of autologous responding $\mathrm{CD} 4^{+}$ T cells incubated with gamma-irradiated allogeneic PBMC; Treg (predn), Treg (rapa), Treg (-) - Treg cells induced in the presence of prednisolone, rapamycin, and with no agent, respectively; Treg (predn) + Tresp - cultures of autologous responding $\mathrm{CD} 4^{+} \mathrm{T}$ cells incubated with stimulatory allogeneic PBMC supplemented with Treg cells that were induced in the presence of prednisolone; PBMC-stim alone-cpm in cultures of gamma-irradiated stimulatory allogeneic PBMC alone. b Proliferation of Treg cells incubated with allogeneic PBMC-stim cells (gamma-irradiated) (PBMC-stim: Treg ratio 1:0.5). c Proliferative response of autologous responding $\mathrm{T} \mathrm{CD} 4^{+}$cells in allogeneic MLR in the presence of different number of Treg cells (Tresp: Treg ratio 1:0.5, 1:0.25, and 1:0.125) generated in cultures with prednisolone. $* p<0.01$, ** $p<0.001$ activity, arresting the cell cycle in G1 phase without blocking production of IL-2 (Li et al. 2014). The drug was found effective in expansion of $\mathrm{CD}^{+} \mathrm{CD} 25^{+} \mathrm{Foxp}^{+}$natural regulatory (tTreg) cells more than decade ago, and is being used in protocols aimed at expansion of polyclonal Treg cells for therapeutic purposes (Alsuliman et al. 2016; Mathew et al. 2018). In our studies we evidenced that rapamycin may effectively promote development of polyclonal iTreg cells that, as suggest our results of a functional assay of their activity in MLR (Fig. 4), could be used in organ transplantation. In contrast to rapamycin, glucocorticoid (GC) effects on cellular regulatory mechanisms have not been investigated sufficiently. GCs are potent anti-inflammatory and immunosuppressive agents that are widely used in autoimmune, inflammatory, and allergic diseases (Coutinho and Chapman 2011). Intuitively, their application should positively affect Treg cell number and/or function in these disorders but results of in vivo studies have been inconclusive: both increased (Mathian et al. 2015; Seissler et al. 2012) and decreased (Olsen et al. 2015; Stock et al. 2005) Treg cell activity, as well as no effect on these cells (Sbiera et al. 2011) were documented following GC treatment. This inconsistencies may result from doses of GC used, time of patients' treatment, type of pathology and initial level of Treg cells, source of cells (peripheral blood vs. locally infiltrating cells), definition of Treg subset etc. Surprisingly, no complex in vitro studies concerning this interesting subject have been performed. The only reliable in vitro study of GC in the context of regulatory $\mathrm{T}$ cells in humans demonstrated induction of Foxp 3 and IL-10 but not TGF- $\beta$ mRNA expression in human $\mathrm{CD} 4^{+} \mathrm{T}$ cells in 6 and $24 \mathrm{~h}$ cultures stimulated with anti-CD2/3/28 antibodies in the presence of IL-2 (Karagiannidis et al. 2004). The cells may be recognized as $\operatorname{Tr} 1$ regulatory cells. In our studies we have unequivocally shown the effect of prednisolone on generation of inducible in vitro Treg cells and, what is interesting, the cells were found to have at least as potent immunosuppressive potential as rapamycin in a functional assay (Fig. 4). The open question is if the similar effect of GC would occur in pure cultures of tTreg cells but some data points on selective effect of GC on pTreg cell development from conventional T cells. As shown by Bereshchenko et al. (2014), GCs stimulate expression of glucocorticoid-induced leucine zipper protein. This protein enhances TGF- $\beta$ signaling by binding to and promoting phosphorylation of Smad2 and activation of Foxp3 expression. Certainly, in the next step of our study aimed at investigation of the effect of prednisolone on generation of Treg cells from naïve $\mathrm{CD} 4{ }^{+} \mathrm{CD} 25^{-} \mathrm{T}$ cells we will resolve this problem.

It is worth noting that steroids exert proapoptotic effect on $\mathrm{T}$ lymphocytes in many settings (Coutinho and Chapman 2011). Indeed, we observed a meaningful inhibitory effect of prednisolone on the number of lymphocytes in stimulated 
Table 3 Effect of prednisolone and rapamycin on stability of in vitro-induced Treg cells $\left(\mathrm{CD} 25^{\text {high }}\right.$ Foxp $3{ }^{\text {high }} \mathrm{CD} 4^{+} \mathrm{T}$ lymphocytes)

\begin{tabular}{|c|c|c|c|}
\hline & Immunomodulator supplemented & $\begin{array}{l}\mathrm{CD} 25^{\text {high }} \mathrm{Fo} \\
\mathrm{CD} 4^{+} \mathrm{T} \text { lyn } \\
(\%) \\
(\text { mean } \pm \mathrm{SD}\end{array}$ & $\begin{array}{l}\mathrm{pp} 3^{\text {high }} \\
\text { phocytes }\end{array}$ \\
\hline \multirow{6}{*}{$\begin{array}{l}\text { Day }+5 \text { (incubation of CD } 4 \text { T cells with CD3/CD28 beads + TGF- } \beta \text { in the pres- } \\
\text { ence or absence of immunomodulators) }\end{array}$} & None & \multicolumn{2}{|l|}{$7.5 \pm 0.01$} \\
\hline & \multicolumn{3}{|l|}{ Prednisolone: } \\
\hline & $\begin{array}{l}2.5 \mu \mathrm{g} / \mathrm{ml} \\
0.25 \mu \mathrm{g} / \mathrm{ml}\end{array}$ & \multicolumn{2}{|l|}{$\begin{array}{l}15.4 \pm 0.02 \\
8.4 \pm 0.00\end{array}$} \\
\hline & \multicolumn{3}{|l|}{ Rapamycin: } \\
\hline & $\begin{array}{l}500 \mathrm{ng} / \mathrm{ml} \\
100 \mathrm{ng} / \mathrm{ml}\end{array}$ & \multicolumn{2}{|l|}{$\begin{array}{l}12.1 \pm 0.01 \\
8.2 \pm 0.01\end{array}$} \\
\hline & & + IL-2 & $-\mathrm{IL}-2$ \\
\hline \multirow{6}{*}{$\begin{array}{l}\text { Day }+9 \text { (prolonged incubation on days } 5-9 \text { with or without IL-2, with no CD3/ } \\
\text { CD28 beads, no TGF- } \beta \text {, and no immunomodulators) }\end{array}$} & Culture conditions on days $0-5$ : & & \\
\hline & None & $2.1 \pm 0.00$ & $1.21 \pm 0.01$ \\
\hline & Prednisolone: & & \\
\hline & $\begin{array}{l}2.5 \mu \mathrm{g} / \mathrm{ml} \\
0.25 \mu \mathrm{g} / \mathrm{ml}\end{array}$ & $\begin{array}{l}7.5 \pm 0.00 \\
6.5 \pm 0.01\end{array}$ & $\begin{array}{l}5.5 \pm 0.01 \\
2.6 \pm 0.00\end{array}$ \\
\hline & Rapamycin: & & \\
\hline & $\begin{array}{l}500 \mathrm{ng} / \mathrm{ml} \\
100 \mathrm{ng} / \mathrm{ml}\end{array}$ & $\begin{array}{l}6.1 \pm 0.00 \\
3.6 \pm 0.01\end{array}$ & $\begin{array}{l}2.8 \pm 0.00 \\
1.5 \pm 0.00\end{array}$ \\
\hline
\end{tabular}

$\mathrm{CD}^{+} \mathrm{T}$ lymphocytes were analyzed following five days of culture with CD3/CD28 beads, TGF- $\beta$, and in the presence or absence of immunomodulators (for details, see "Materials and Methods") (day +5 , upper part of the table). On the day 5, culture medium was replaced with medium containing either IL-2 or no cytokine and the cells were analyzed following prolonged four-day incubation (day +9 , lower part of the table). Samples were tested in duplicates

Table 4 Effects of prednisolone and rapamycin on cytokine production in cultures of iTreg cells

\begin{tabular}{llcr}
\hline Incubation conditions & \multicolumn{3}{l}{$\begin{array}{l}\text { Concentration of cytokines in supernatants }(\mathrm{pg} / \mathrm{ml}) \\
(\text { mean } \pm \text { SD })(n=3)\end{array}$} \\
\cline { 2 - 4 } & \multicolumn{1}{l}{ IL-10 } & IL-6 & TNF- $\alpha$ \\
\hline CD3/CD28 beads & $20.1 \pm 10.5$ & $51.5 \pm 22.7$ & $66.3 \pm 20.5$ \\
+ TGF- $\beta$ & $17.5 \pm 7.7$ & $67.1 \pm 43.4$ & $100.1 \pm 31.1$ \\
+ TGF- $\beta$ + prednisolone $(2.5 \mu \mathrm{g} / \mathrm{ml})$ & $15.7 \pm 7.5$ & $3.4 \pm 1.4$ & $22.3 \pm 13.4$ \\
+ TGF- $\beta$ + prednisolone $(0.25 \mu \mathrm{g} / \mathrm{ml})$ & $27.1 \pm 8.5$ & $11.1 \pm 6.2$ & $43.5 \pm 16.6$ \\
+ TGF- $\beta+$ rapamycin $(500 \mathrm{ng} / \mathrm{ml})$ & $11.7 \pm 3.6$ & $73.7 \pm 46.1$ & $174.9 \pm 71$ \\
+ TGF- $\beta+$ rapamycin $(100 \mathrm{ng} / \mathrm{ml})$ & $21.2 \pm 17.2$ & $98.8 \pm 93.4$ & $307.4 \pm 199.7$ \\
\hline
\end{tabular}

iTreg cells were induced in the presence of prednisolone or rapamycin for 5 days, as described in "Material and Methods". On day 5, culture supernatants were discarded and replaced with fresh culture medium. After 2-day resting period supernatants were harvested, centrifuged, and kept frozen until the cytokine analysis procedure
T cell cultures incubated with TGF- $\beta$ but only in cultures incubated with the highest concentrations of prednisolone. In fact, recovery of lymphocytes for FACS analysis was higher in prednisolone than rapamycin-cultivated $\mathrm{CD} 4^{+} \mathrm{T}$ cells (Table 1).

Another question is if iTreg-inducing effect of prednisolone which is observed in vitro can be translated in vivo. Since concentration of prednisolone in serum up to $1 \mu \mathrm{g} / \mathrm{ml}$ was detected following single oral administration of the drug (Gai et al. 2005), it is highly probable that immunomodulatory effect of glucocorticoids on Treg cells may appear in vivo.
Sustained Foxp3 expression is necessary for immunosuppressive cell activity (Gao et al. 2012). However, this transcription factor may be transiently expressed in a high percentage of activated $\mathrm{T}$ cells after in vitro stimulation of human $\mathrm{CD} 4^{+} \mathrm{CD} 25^{-}$cells (Wang et al. 2007). Such expression is associated with low responsiveness of these cells, but they lack significant suppressive capacity. Nevertheless, Tregs express higher level of Foxp3 than activated $\mathrm{CD} 4{ }^{+} \mathrm{CD} 25^{-}$cells. Thus determination of MFI of Foxp3 should be used as a way to discriminate the cells having suppressive abilities from activated $\mathrm{CD} 4{ }^{+} \mathrm{CD} 25^{+} \mathrm{T}$ cells devoid of regulatory potential. 
Other issue is the functional stability of in vitro-induced Tregs. At present, the most reliable way to show Treg stability is verification of demethylation pattern in TSDR. Although TSDR in tTregs is demethylated, in vitro induction of iTregs with TGF- $\beta$ does not lead to demethylation of TSDR (Ohkura et al. 2012). Nevertheless, functionality of in vitro induced iTreg cells was shown both in vitro and in vivo (Hippen et al. 2011). Addition of some agents to Treg-inducing protocols may increase their function in vivo even to greater extent (Lee et al. 2012). Results of our studies are in agreement with the latter one, showing clearly that rapamycin and especially prednisolone, when present during Treg-inducing phase, can promote development of higher number of Treg cells. However, the matter is unknown how long these iTreg cells will retain their suppressive activity in vivo.

In summary, our studies have shown different potential of a panel of immunomodulatory pharmaceutical agents to promote development of Treg cells. Our findings may be helpful in developing the most effective protocols of $\mathrm{T}$ regulatory lymphocytes' induction. The most interesting finding of our studies is showing unequivocal and strong Treg-inducing effect of prednisolone. This effect may contribute to immunosuppressive and anti-inflammatory property of glucocorticoids observed in vivo. Since prednisolone seems as optimal as rapamycin in stimulating iTreg cells, preparation of prednisolone-generated Treg cells could be considered as an option for adoptive cellular treatment.

Acknowledgements The study was supported by the "Diamentowy Grant" DI 2014019244 programme financed by Polish Ministry of Science and Higher Education.

\section{Compliance with Ethical Standards}

Conflict of interest The author(s) declare that they have no competing interests.

Open Access This article is licensed under a Creative Commons Attribution 4.0 International License, which permits use, sharing, adaptation, distribution and reproduction in any medium or format, as long as you give appropriate credit to the original author(s) and the source, provide a link to the Creative Commons licence, and indicate if changes were made. The images or other third party material in this article are included in the article's Creative Commons licence, unless indicated otherwise in a credit line to the material. If material is not included in the article's Creative Commons licence and your intended use is not permitted by statutory regulation or exceeds the permitted use, you will need to obtain permission directly from the copyright holder. To view a copy of this licence, visit http://creativecommons.org/licenses/by/4.0/.

\section{References}

Abbas AK, Benoist C, Bluestone JA et al (2013) Regulatory T cells: recommendations to simplify the nomenclature. Nat Immunol $14: 307-308$
Alsuliman A, Appel SH, Beers DR et al (2016) A robust, good manufacturing practice-compliant, clinical-scale procedure to generate regulatory $\mathrm{T}$ cells from patients with amyotrophic lateral sclerosis for adoptive cell therapy. Cytotherapy 18:1312-1324

Arpaia N, Campbell C, Fan X et al (2013) Metabolites produced by commensal bacteria promote peripheral regulatory T-cell generation. Nature 504:451-455

Bereshchenko O, Coppo M, Bruscoli S et al (2014) GILZ promotes production of peripherally induced Treg cells and mediates the crosstalk between glucocorticoids and TGF- $\beta$ signaling. Cell Rep 7:464-475

Bocian K, Kiernozek E, Domagała-Kulawik J et al (2017) Expanding diversity and common goal of regulatory $\mathrm{T}$ and $\mathrm{B}$ cells. I: Origin, phenotype, mechanisms. Arch Immunol Ther Exp 65:501-520

Campoli-Richards DM, Sorkin EM, Heel RC (1986) Inosine Pranobex. Drugs 32:383-424

Candia E, Reyes P, Covian C et al (2017) Single and combined effect of retinoic acid and rapamycin modulate the generation, activity and homing potential of induced human regulatory T cells. PLoS ONE 12:e0182009

Coutinho AE, Chapman KE (2011) The anti-inflammatory and immunosuppressive effects of glucocorticoids, recent developments and mechanistic insights. Mol Cell Endocrinol 335:2-13

Fanigliulo D, Lazzerini PE, Capecchi PL et al (2015) Clinically-relevant cyclosporin and rapamycin concentrations enhance regulatory $\mathrm{T}$ cell function to a similar extent but with different mechanisms: an in-vitro study in healthy humans. Int Immunopharmacol $24: 276-284$

Fontenelle B, Gilbert KM (2012) $n$-Butyrate anergized effector CD4 ${ }^{+} \mathrm{T}$ cells independent of regulatory $\mathrm{T}$ cell generation or activity. Scand J Immunol 76:457-463

Forero-Peña DA, Gutierrez FR (2013) Statins as modulators of regulatory T-cell biology. Mediators Inflamm 2013:167086

Fu XQ, Cai JY, Huang QY et al (2017) Prednisone may induce immunologic tolerance by activating the functions of decidual immune cells in early pregnancy. Oncotarget 8:102191-102198

Gai MN, Pinilla E, Paulos C et al (2005) Determination of prednisolone and prednisone in plasma, whole blood, urine, and boundto-plasma proteins by high-performance liquid chromatography. J Chromatogr Sci 43:201-206

Gao Y, Lin F, Su J et al (2012) Molecular mechanisms underlying the regulation and functional plasticity of FOXP3+ regulatory T cells. Genes Immun 13:1-13

Gliwiński M, Iwaszkiewicz-Grześ D, Trzonkowski P (2017) Cell-based therapies with T regulatory cells. BioDrugs 31:335-347

Guasti L, Maresca AM, Schembri L et al (2016) Relationship between regulatory $\mathrm{T}$ cells subsets and lipid profile in dyslipidemic patients: a longitudinal study during atorvastatin treatment. BMC Cardiovasc Disord 16:26

Haas J, Korporal M, Balint B et al (2009) Glatiramer acetate improves regulatory $\mathrm{T}$-cell function by expansion of naive CD4+CD25+FOXP3+CD31+ T-cells in patients with multiple sclerosis. J Neuroimmunol 216:113-117

Hippen KL, Merkel SC, Schirm DK et al (2011) Generation and largescale expansion of human inducible regulatory T cells that suppress graft-versus-host disease. Am J Transplant 11:1148-1157

Hong J, Li N, Zhang X et al (2005) Induction of CD4+CD25+ regulatory $\mathrm{T}$ cells by copolymer-I through activation of transcription factor Foxp3. Proc Natl Acad Sci USA 102:6449-6454

Horwitz DA, Zheng SG, Gray JD (2008) Natural and TGF- $\beta$-induced Foxp3+CD4+ CD25+ regulatory $\mathrm{T}$ cells are not mirror images of each other. Trends Immunol 29:429-435

Karagiannidis C, Akdis M, Holopainen P et al (2004) Glucocorticoids upregulate FOXP3 expression and regulatory $\mathrm{T}$ cells in asthma. $\mathrm{J}$ Allergy Clin Immunol 114:1425-1433 
Kretschmer K, Apostolou I, Hawiger D et al (2005) Inducing and expanding regulatory $\mathrm{T}$ cell populations by foreign antigen. Nat Immunol 6:1219-1227

Lan Q, Fan H, Quesniaux V et al (2012) Induced Foxp3+ regulatory T cells: a potential new weapon to treat autoimmune and inflammatory diseases? J Mol Cell Biol 4:22-28

Lasek W, Janyst M, Wolny R et al (2015) Immunomodulatory effects of inosine pranobex on cytokine production by human lymphocytes. Acta Pharm 65:171-180

Lee JH, Lydon JP, Kim CH (2012) Progesterone suppresses the mTOR pathway and promotes generation of induced regulatory $\mathrm{T}$ cells with increased stability. Eur J Immunol 42:2683-2696

Lee SA, Noel S, Sadasivam M et al (2017) Role of immune cells in acute kidney injury and repair. Nephron 137:282-286

Li J, Kim SG, Blenis J (2014) Rapamycin: one drug, many effects. Cell Metab 19:373-379

Liu W, Putnam AL, Xu-yu Z et al (2006) CD127 expression inversely correlates with FoxP3 and suppressive function of human CD4 ${ }^{+}$ T reg cells. J Exp Med 203:1701-1711

Lu L, Lan Q, Li Z et al (2014) Critical role of all-trans retinoic acid in stabilizing human natural regulatory T cells under inflammatory conditions. Proc Natl Acad Sci USA 111:E3432-3440

Majewska A, Lasek W, Janyst M et al (2015) Inhibition of adenovirus multiplication by inosine pranobex and interferon $\alpha$ in vitro. Cent Eur J Immunol 40:395-399

Martín-Orozco E, Norte-Muñoz M, Martínez-García J (2017) Regulatory $\mathrm{T}$ cells in allergy and asthma. Front Pediatr 5:117

Mathew JM, Voss J, LeFever A et al (2018) A phase I clinical trial with ex vivo expanded recipient regulatory $\mathrm{T}$ cells in living donor kidney transplants. Sci Rep 8:7428

Mathian A, Jouenne R, Chader D et al (2015) Regulatory T cell responses to high-dose methylprednisolone in active systemic lupus erythematosus. PLoS ONE 10:e0143689

Mausner-Fainberg K, Luboshits G, Mor A et al (2008) The effect of HMG-CoA reductase inhibitors on naturally occurring CD4+CD25+ T cells. Atherosclerosis 197:829-839

Mitsikostas DD, Goodin DS (2017) Comparing the efficacy of diseasemodifying therapies in multiple sclerosis. Mult Scler Relat Disord 18:109-116

Ohkura N, Hamaguchi M, Morikawa H et al (2012) T Cell receptor stimulation-induced epigenetic changes and Foxp3 expression are independent and complementary events required for Treg cell development. Immunity 37:785-799

Olsen PC, Kitoko JZ, Ferreira TP et al (2015) Glucocorticoids decrease Treg cell numbers in lungs of allergic mice. Eur J Pharmacol 747:52-58
Sakaguchi S, Yamaguchi T, Nomura T et al (2008) Regulatory T cells and immune tolerance. Cell 133:775-787

Sbiera S, Dexneit T, Reichardt SD et al (2011) Influence of short-term glucocorticoid therapy on regulatory T cells in vivo. PLoS ONE 6:e24345

Schmidt A, Eriksson M, Shang MM et al (2016) Comparative analysis of protocols to induce human CD4+Foxp3+ regulatory T cells by combinations of IL-2, TGF-beta, retinoic acid, rapamycin and butyrate. PLoS ONE 11:e0148474

Schmitt EG, Williams CB (2013) Generation and function of induced regulatory T cells. Front Immunol 4:152

Seissler N, Schmitt E, Hug F et al (2012) Methylprednisolone treatment increases the proportion of the highly suppressive HLA-DR+Treg-cells in transplanted patients. Transpl Immunol 27:157-161

Spadaro M, Montarolo F, Perga S et al (2017) Biological activity of glatiramer acetate on Treg and anti-inflammatory monocytes persists for more than 10 years in responder multiple sclerosis patients. Clin Immunol 181:83-88

Stock P, Akbari O, DeKruyff RH et al (2005) Respiratory tolerance is inhibited by the administration of corticosteroids. J Immunol 175:7380-7387

Trzonkowski P, Bieniaszewska M, Juścińska J et al (2009a) First-inman clinical results of the treatment of patients with graft versus host disease with human ex vivo expanded CD4+CD25+CD127T regulatory cells. Clin Immunol 133:22-26

Trzonkowski P, Szaryńska M, Myśliwska J et al (2009b) Ex vivo expansion of $\mathrm{CD} 4{ }^{+} \mathrm{CD} 25^{+} \mathrm{T}$ regulatory cells for immunosuppressive therapy. Cytom A 75:175-188

Wang J, Ioan-Facsinay A, van der Voort EIH et al (2007) Transient expression of FOXP3 in human activated nonregulatory CD4+ T cells. Eur J Immunol 37:129-138

Whibley N, Tucci A, Powrie F (2019) Regulatory T cell adaptation in the intestine and skin. Nat Immunol 20:386-396

Zahran A, Saad K, Abdel-Raheem YF et al (2019) Characterization of regulatory $\mathrm{T}$ cells inpreterm and term infants. Arch Immunol Ther Exp 67:49-54

Zheng SG, Gray JD, Ohtsuka K et al (2002) Generation ex vivo of TGF- $\beta$-producing regulatory $\mathrm{T}$ cells from $\mathrm{CD} 4^{+} \mathrm{CD} 25^{-}$precursors. J Immunol 169:4183-4189

Publisher's Note Springer Nature remains neutral with regard to jurisdictional claims in published maps and institutional affiliations. 